Warszawa, 03 lutego 2021 r.

\title{
REKOMENDACJA KOMITETU NAUK PRAWNYCH POLSKIEJ AKADEMII NAUK W SPRAWIE UJAWNIANIA KONFLIKTU INTERESÓW W PRAWNICZYCH PUBLIKACJACH NAUKOWYCH
}

W celu podnoszenia jakości polskich wydawnictw naukowych, w tym czasopism prawniczych, a także w obliczu informacji o pojawiających się nieprawidłowych praktykach w publikowaniu nacechowanych stronniczością wyników badań i analiz w naukach prawnych, Komitet Nauk Prawnych PAN zaleca redakcjom prawniczych wydawnictw i czasopism naukowych rozważenie potrzeby wprowadzenie do polityki wydawniczej poniższych klauzul dotyczących ujawniania występowania konfliktu interesów.

Zalecenie to wynika nie tylko $\mathrm{z}$ wymogów nakładanych $\mathrm{w}$ tym zakresie na redakcje przez instytucje zarządzające międzynarodowymi bazami referencyjnymi czasopism naukowych, ale przede wszystkim ma zachęcić autorki i autorów do rozwagi w zakresie łączenia różnych ról zawodowych pełnionych $\mathrm{w}$ ramach środowiska naukowego i poza nim. Rolą niniejszej rekomendacji jest także dążenie do zwiększenia transparentności w podejmowanych działaniach naukowych.

\section{Pojęcie konfliktu interesów}

Konflikt interesów jest zgłaszany redakcji przez autorkę lub autora, którzy uważaja, że w ich ocenie pełnione przez nie i przez nich poza akademią role moga wpływać lub mogą być uznane przez osoby trzecie za wpływające na ich obiektywizm podczas prowadzenia badań lub prezentacji ich wyników.

Konflikt interesów może mieć miejsce w przypadku występowania związków autorek lub autorów z instytucja, przedsiębiorstwem lub urzędem publicznym (zwanych dalej łącznie instytucja), które są bezpośrednio zainteresowane lub czerpią korzyści z przyjęcia określonej interpretacji prawa. Chodzi tu o związki polegające na:

pracy w danej instytucji, także na podstawie umowy o dzieło lub zlecenia, odpłatnego reprezentowania jej jako pełnomocnik lub występowania w jej imieniu lub na jej rzecz jako ekspertka lub ekspert (w toku prac nad tekstem lub w ciagu ostatnich 3 lat), w szczególności gdy zgłoszony do druku tekst jest 
powtórzeniem lub przerobioną wersją pisma procesowego czy opinii przygotowanej dla danej instytucji;

braniu przez autorkę lub autora udziału w wydaniu orzeczenia czy rozstrzygnięcia sądu bądź innego organu, które następnie analizują w zgłoszonej publikacji naukowej;

korzystaniu ze środków danej instytucji na przeprowadzenie badań - zarówno będących przedmiotem publikowanego artykułu, jak również innych przeszłych (przeprowadzonych w ciagu ostatnich 3 lat) lub obecnie prowadzonych badań, w tym pokrycia kosztów ich publikacji.

\section{Procedura publikacji uwzględniająca kwestie konfliktu interesów:}

Przy zgłaszaniu tekstów do czasopisma, autorki lub autorzy informuja redakcję, czy uważaja, że w ich przypadku może zachodzić konflikt interesów w opisanym wyżej znaczeniu. Redakcje czasopism zmodyfikują swoje wytyczne, regulaminy lub formularze zgłoszeń, by umożliwić złożenie takiego oświadczenia.

Wystapienie konfliktu interesów nie oznacza, że przygotowany tekst nie może lub nie powinien zostać opublikowany, pod warunkiem jednak, że wskazane związki z instytucjami nie wpływają na rzetelność i prawidłowość dowodu naukowego oraz jakość przeprowadzonych badań prezentowanych w publikacji naukowej.

Osoba recenzująca powinna zostać poinformowana o fakcie zgłoszenia konfliktu interesów (bez ujawniania jego natury). Dzięki temu w recenzji będzie mogła ocenić, czy - mimo zgłoszonego konfliktu - od strony naukowej tekst został przygotowany rzetelnie i zawiera obiektywne analizy oraz wyniki badań.

Jako dobra praktykę redakcje czasopism powinny rozważyć publikację przy każdym z tekstów (jako stałego elementu układu typograficznego) oświadczeń co do występowania konfliktu interesów.

Nieujawnienie informacji o konflikcie interesów stanowi naruszenie zasad etyki i dobrych obyczajów naukowych.

Powyższe zalecenia należy odpowiednio stosować w procedurach wydawniczych dotyczacych innych publikacji naukowych, np. monografii czy prac zbiorowych.

W imieniu KNP PAN

prof. dr hab. Robert Grzeszczak przewodniczący KNP PAN 


\section{INFORMACJE DLA AUTORÓW}

1. Objętość nadsyłanych tekstów nie może przekraczać 1 ark. wyd. (36-40 tys. znaków wraz ze spacjami i przypisami) w wypadku artykułu. Obliczając objętość tekstu, należy wziąć pod uwagę, że obejmuje ona również wykaz cytowanej literatury, a także tabele i ryciny. Objętość recenzji nie powinna przekraczać 10 tys. znaków.

2. Zgłaszany tekst powinien być zanonimizowany $-\mathrm{z}$ tekstu głównego i przypisów, a także z metadanych pliku należy usunąć wszelkie informacje pozwalające zidentyfikować autora/autorów (np. o grantach).

3. W zgłoszeniu należy podać dane o autorze/autorach, adres do korespondencji, numery telefonów i adres służbowej (instytucjonalnej) poczty elektronicznej, a także identyfikator ORCID. W wypadku pracowników naukowych prosimy także o podanie nazwy i adresu uczelni macierzystej.

4. Teksty należy przesyłać za pośrednictwem platformy elektronicznej: https://pressto.amu.edu.pl/index.php/rpeis/about/submissions.

5. Wszelkie tabele, wykresy lub ryciny będące częścią tekstu należy również przesyłać w formie edytowalnego zapisu elektronicznego. Minimalna grubość linii rysunku powinna wynosić $0,4 \mathrm{pkt}$, a rysunki należy sporządzić w wersji czarno-białej, w formacie nie większym niż format kolumny $(126 \times 180 \mathrm{~mm})$.

6. Do artykułu należy dołączyć krótkie streszczenia (abstrakty) w języku polskim i angielskim (ok. 1,5 tys. znaków) oraz słowa kluczowe.

7. Do przesłanej propozycji publikacji należy dołączyć oświadczenie (dostępne na: www.rpeis.pl). Po przyjęciu tekstu do druku autor podpisuje umowę wydawniczą z czasopismem.

8. Termin wykonania korekty autorskiej wynosi maksymalnie 1 tydzień Po upływie tego terminu tekst kierujemy do publikacji wyłącznie z korekta redakcyjna.

9. Zgłoszenie artykułu, proces recenzyjny oraz publikacja w RPEiS są bezpłatne.

10. Publikacja w RPEiS oznacza zgodę na zdeponowanie tekstu w wersji elektronicznej w repozytoriach, bazach i na platformach indeksujacych i upowszechniających treści naukowe.

Szczegółowe zasady edytorskie dostępne na www.rpeis.pl 


\section{SUBMISSION GUIDELINES}

1. The length of manuscripts submitted to RPEiS must not exceed 36,00040,000 characters (6,000 words), including spacing and footnotes, reference list, and tables and figures, in the case of articles, and a maximum of 10,000 characters (1,500 words) for reviews.

2. The submitted text should be anonymized - any information making it possible to identify the author(s) (for example, concerning grants) should be removed from the main text and footnotes, as well as from the file metadata.

3. The author's personal details, correspondence address, telephone numbers and institutional email address as well as ORCID identifier must be attached. In the case of academic staff, we also request the name and address of their university.

4. Manuscripts should be submitted via https://pressto.amu.edu.pl/index. php/rpeis/about/submissions.

5. All tables, graphs or graphics in the body of the text must be sent in enable-editing electronic form. The minimum line width should be $0.4 \mathrm{pts}$ and figures should be in black and white, in a form that does not exceed the format of a $128 \times 180 \mathrm{~mm}$ column.

6. A short abstract, in Polish and English, must be attached (1,500 characters/ 250 words) with a list of keywords.

7. A declaration must be attached to the application for publication (available at www.rpeis.amu.edu.pl). After the text has been accepted for publication, the author will sign a publishing agreement with the journal.

8. The deadline for authors' revisions is one week. Thereafter the manuscript will be sent for publication with the editors' revisions only.

9. There are no fees for submitting, processing or publishing an article in RPEiS.

10. Publication in RPEiS implies that the author consents to the electronic location of the text in repositories, databases and platforms indexing and disseminating scientific content.

More on editorial principles at www.rpeis.pl 